\title{
Responses of grassland arthropods to various biodiversity-friendly management practices: Is there a compromise?
}

\author{
Monika MAZALOVÁ ${ }^{1}$, JAN ŠIPOŠ², STANISLAV RADA ${ }^{1}$, JoseF KAŠÁK ${ }^{3}$, BoŘIVoJ ŠARAPATKA ${ }^{1}$ and TomÁš KURAS ${ }^{1}$ \\ ${ }^{1}$ Department of Ecology and Environmental Sciences, Faculty of Science, Palacky University, Šlechtitelů 241/27, \\ 78371 Olomouc - Holice, Czech Republic; e-mails: mazalka.m@seznam.cz; stanislav.rada@seznam.cz; \\ borivoj.sarapatka@upol.cz; kurast@seznam.cz \\ ${ }^{2}$ Department of Biology and Ecology, Faculty of Science, University of Ostrava, Chittussiho 10, 710 00, Slezská Ostrava, \\ Czech Republic; e-mail: jsipos@seznam.cz \\ ${ }^{3}$ Department of Forest Protection and Wildlife Management, Faculty of Forestry and Wood Technology, Mendel University in Brno, \\ Zemědělská 810/3, 61300 Brno - Černá Pole, Czech Republic; e-mail: josef.kasak@mendelu.cz
}

Key words. Arthropods, functional diversity, grasslands, mowing, grazing, landscape structure, Czech Republic, Jeseníky Mts

\begin{abstract}
The rich species pool in semi-natural grasslands is associated with high spatial and temporal heterogeneity. This empirical study is one of the first to jointly analyze the response of orders, individual species and functional richness of arthropods to particular management practices and to linear landscape features, such as strips of grass and belts of trees. Mostly it was the less mobile, flightless taxa that were negatively affected by immediate disturbance caused by mowing. At a larger time-scale, grasslands managed by mowing once every year, and especially by a combined regime of mowing and grazing, supported the highest species richness of butterflies and beetles. Most functional diversity measures reached maximum values soon after mowing. Both strips of grass and belts of trees substantially affected the invertebrate community structure as the majority of taxa were positively associated with these linear features. Based on our results, we propose postponing mowing to later in the year, mowing in gradual stages, maintaining uncut strips primarily along permanent landscape features and establishing both strips of grass and belts of trees in submontane grassland environments.
\end{abstract}

\section{INTRODUCTION}

A substantial proportion of the Central European biodiversity occurs in semi-natural grasslands. Existence of this widespread type of open habitat is dependent on disturbance, which prevents succession towards forest. Nonforest areas were traditionally maintained by grazing and hay-making (Duffey et al., 1974). Both types of land use differed in terms of intensity of use, which often fluctuated in space and time, creating a wide spectrum of microhabitats and promoting high species richness and diversity (Benton et al., 2003; Davies et al., 2005). The 20th century brought two interrelated trends, both of which led to the loss of spatial and temporal heterogeneity. This resulted in a depletion of originally diverse communities of grasslands. Former meadows and pastures were either transformed into consolidated blocks of arable land and productive grasslands, or were abandoned and gradually overgrown by forest (Stoate at al., 2001, 2009; Robinson \& Sutherland, 2002). Currently, over $50 \%$ of the earlier extent of grasslands has been lost in the Czech Republic (Skaloš, 2006). Not only the loss of area but also structural changes (Skaloš et al., 2011) in the remaining or even newly formed grasslands may be the reason for the noticeable decline in diversity (Benton et al., 2003; Holuša, 2012). Persistent fragments of former grasslands are mainly merged into blocks of land that are on average 5-10 times larger than half a century ago (Plesník \& Staňková 2001). Former hedgerows, buffer strips of grass and trees, important elements of spatial heterogeneity, were lost during the collectivisation of land that culminated in the 1970s and 1980s (Konvicka et al., 2008). Temporal heterogeneity rapidly declines as modern hay harvesting machinery removes grass from extensive areas in a very short time span (Cizek et al., 2012; Buri et al., 2014). Despite the above, semi-natural grasslands still play a key role in the preservation of a considerable part of non-forest biodiversity associated with the cultural landscape in Europe (Poschlod \& WallisDeVries, 2002; Woodcock et al., 2005; Baur et al., 2006).

In this study we evaluate the association of invertebrate communities in submontane meadows and pastures in the Czech Republic with agricultural management and local landscape structure. There is an extensive literature on the association of particular taxa of invertebrates with mowing, grazing and landscape structure (e.g., Schmidt et al., 2005; Ekroos et al., 2010; Humbert et al., 2010). However, studies on the complex effect of often combined management practises and landscape complexity on real farmland conditions are noticeably scarcer. The majority of these studies are on one or a few taxonomic groups, not on the whole range of arthropod taxa (but see Kruess \& Tscharntke, 2002; Debano, 2006; Sjödin et al., 2008; Cizek et al., 2012). Moreover, relatively little is known about the functional consequences of agricultural management. Functional diversity (FD) can be defined as the range, dispersion, and relative abundance of functional traits of organisms in a given ecosystem (Mouchet et al., 2010). As the consensus is that high diversity (functional diversity included) ensures more complex ecosystem services (e.g., 
Cadott et al., 2011; Isbell et al., 2011) we included FD in our study.

We evaluated the association of the community structure of invertebrates with various types of grassland management, with particular reference to both the immediate effects of mowing and grazing and the long-term effects of each management treatment. Additionally, we focused on the effect of local landscape structures (i.e., strips of grass and belts of trees and shrubs). Arthropod communities were investigated at two taxonomic levels: (i) number of individuals belonging to each of the orders, and (ii) abundance of beetles (Coleoptera), butterflies and burnet moths (Zygaenidae) of Lepidoptera, and bumblebees of Hymenoptera.

\section{MATERIAL AND METHODS}

\section{Study area}

This study was carried out in a submontane area (ca. 750-800 $m$ a.s.l.) in the Hrubý Jeseník Mts, in the north-eastern part of the Czech Republic. The permanent grassland $\left(50^{\circ} 6^{\prime} 39^{\prime \prime} \mathrm{N}\right.$, $\left.17^{\circ} 3^{\prime} 14^{\prime \prime} \mathrm{E}\right)$ close to the village Nové Losiny is almost completely surrounded by extensive forest and covers an area of about 180 ha. The research area was situated in the eastern, more heterogeneous and better preserved part of this grassland complex ( $80 \mathrm{ha})$, with semi-natural hay meadows and pastures managed as part of the Czech agri-environmental scheme (AES) for at least 5 years (Fig. 1). Units of land are usually bounded by strips of grass or belts of trees.

\section{Arthropods studied}

We investigated the effects of agricultural management and local landscape structure on arthropods. First, we recorded the numbers of individuals in all the invertebrate orders that were abundant in the samples. This required less time and effort (Andersen, 1995) but, nevertheless, provided an indication of the responses of the whole community to environmental change (i.e., management). Recent studies indicate that taxonomic diversity determined on the basis of the proportion of the different orders in a community can be used to indicate environmental changes (e.g., Biaggini et al., 2007; Tanabe et al., 2008).

Second, we focused in detail on three groups of insects with different life histories, all of which are often used as models in conservation studies. Butterflies and burnet moths (Zygaenidae), bumblebees and cuckoo-bees of the subgenus Psithyrus (sensu Cameron et al., 2007) and Coleoptera. All three groups are viewed as important bioindicators of treeless habitats. Since these groups differ in their life histories and occupy different functional niches they may respond differently to various management practices as well as other habitat characteristics.

\section{Sampling method}

We used yellow pan water traps (YPWT; Moericke, 1951) deployed along transects across all patches. Although YPWT are generally used for sampling flower-visiting insects (Kuras et al., 2000; Monsevičius, 2004; Campbell \& Hanula, 2007; Wilson et al., 2008) they provide a standardized method of sampling mainly flying insects at different sites (Wilson et al., 2008). Moreover, previous studies successfully used this method for other guilds of invertebrates, e.g., Homoptera (Mochida \& Suryana, 1976; Boiteau, 1990), Araneae (Blades \& Marshall, 1994), Orthoptera (Evans \& Bailey, 1993) and Coleoptera (Leksono et al., 2005). The YPWT were plastic bowls $15 \mathrm{~cm}$ in diameter and $8 \mathrm{~cm}$ deep filled with a preserving liquid (water solution of sodium chloride

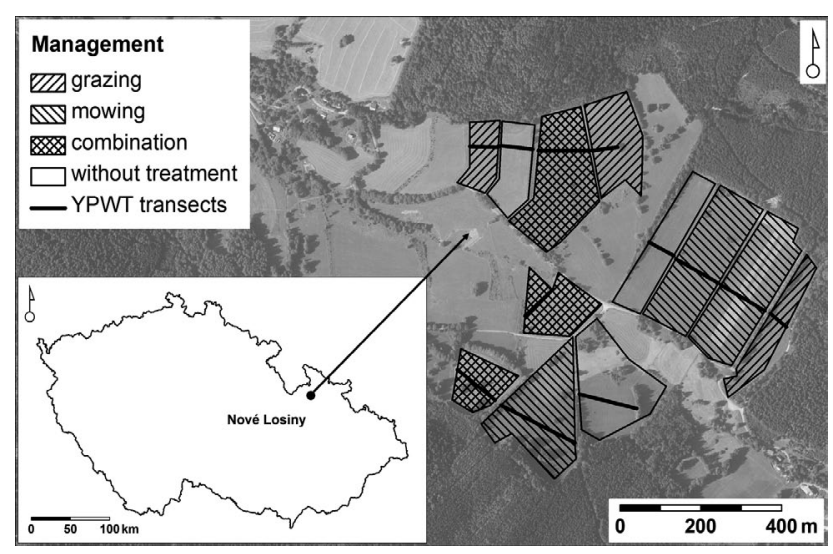

Fig. 1. Map showing the location of the study area in the Czech Republic, positions of patches with different long-term management treatments and positions of transects within the patches.

plus commercial detergent). They were placed on the ground and the surrounding vegetation was cut and removed in a circle $(\mathrm{d}=$ $1 \mathrm{~m}$ ) around the trap to avoid shading and biased sampling. The YPWT were operated from the end of May until the end of August in the first season of the investigation (2009) and from the $3^{\text {rd }}$ week of June until the penultimate week of September in the second year (2010). We had to postpone the first date of sampling due to unfavourable weather conditions in the spring of 2010 . The samples were collected at approximately ten-day intervals, ten times during each field season. Each sample was preserved in $95 \%$ ethanol. All specimens were sorted to orders and counted. Butterflies, bumblebees and beetles were identified to species, except the small herbivorous beetles, which were identified to family level (mostly Mordellidae, Nitidulidae, some representatives of Chrysomelidae). These specimens were only included in the analyses at the level of orders. The nomenclature followed the Fauna Europaea database (version 2.5.; http://www.faunaeur. org.).

\section{Sampling design}

We studied four types of grassland management: (i) mowing, (ii) cattle grazing, (iii) combination of mowing and grazing and (iv) "no management" during the vegetation season $(\mathrm{N})$. These treatments were carried out for at least five consecutive years. Moreover, we focused on the actual effect of cutting and grazing on arthropods. Grazing intensity was lower than 1 cow/ha (specifically in the grazed patches it was 0.82 and 0.84 cows/ha). The meadows were not fertilized and were cut once a year using a roller mower without conditioner (cutting height $6 \mathrm{~cm}$ ). In the first year of the study (2009), the meadows were mown in the first week of July. In the second year, the area was mown gradually in six steps between $29^{\text {th }}$ of June 2010 and the $25^{\text {th }}$ of August 2010. The cattle grazing started in mid-June and lasted for 30 days. The sites subjected to both mowing and grazing were mown earlier, in the first week of July, and then grazed for approximately one month from the last week of August to the last week of September. At the "no management" patches the vegetation cover was left uncut and was not grazed throughout the vegetation period (but was mown in late autumn).

The design of the survey consisted of 12 patches of grassland arranged in three units each of which included the four management treatments (Fig. 1).

The patches were situated on plains or gentle slopes. The study plots selected were at similar altitudes (from 750 to $780 \mathrm{~m}$ a.s.l.) and inclinations. Average size of the patches was 2.38 ha (the smallest covered an area of 1.16 ha, the largest 4.81 ha). All the 
patches were delimited by distinct boundaries - belts of trees, forest edges or strips of grass. We distinguished two types of boundaries: strips of grass and belts of trees. The strips of grass were perennial treeless strips (width $5-10 \mathrm{~m}$ ) and belts of trees were strips with mature trees that provided shade (width 10-15 m).

Transects ran from one edge of a particular patch (formed either by strip of grass or belt of trees) towards another edge. The distance between traps was 20-25 m. There were a total of 35 traps in the mowed patches, 11 in the grazed patches and 13 in the patches subjected to a combination of grazing and mowing. There were 21 traps in patches that were not managed during the vegetation season and 8 traps in the linear boundaries to the patches (i.e., strips of grass or belts of trees). The number of traps in each patch of a particular management treatment corresponded to the area of the patches subject to that particular treatment.

\section{Data arrangement}

We first studied the community structure of grassland invertebrates associated with the different grazing and mowing treatments. The explanatory variables were mowing and grazing, both of them tested in interaction with time (to control for seasonality). Mowing was coded as an ordinal variable on the following scale: $1,0.5,0.25,0$, which corresponds to the gradual restoration of the sward after disturbance. Immediately after mowing the value was 1 , gradually decreasing in the following 10 -days periods $(0.5$; $0.25)$, reaching zero ( 0 ) after 30 days from the date of mowing. We defined these values based the time the sward took to recover after treatment, which was recorded during regular fieldwork. The factor grazing was a binary variable, as grazing intensity was low and equal at all sites. Time was individually coded for each collection date as the number of days since the beginning of the year. Replication units for these analyses were the samples for each collection date (a total of 20 collections, 10 for each of the two seasons of this study) pooled for each of the 12 patches.

We then focused on long-term effects of four types of management (i.e., mowing, grazing, both treatments, no management during the vegetation season) on the number of species and orders recorded on the areas subjected to the different treatments. These were investigated by comparing the rarefaction curves of the four management treatments. In this case, all the samples collected for particular management sites were pooled.

Finally, the effect of the two linear landscape structures was assessed using ordination. The distances in metres from the nearest strip of grass and belt of trees were individually recorded for each YPWT. Therefore, the replication unit was each trap (i.e., all the samples from a particular trap collected during the experimental period were pooled).

The response variables used in the ordination analyses and GLM were (i) number of individuals belonging to each order of invertebrates and (ii) number of individuals of each species belonging to the three targeted groups. Pooled numbers of representatives either of orders or of species within the three groups was used for the construction of rarefaction curves.

To remove negative effect of possible confounding factors on the trap samples we used abundance of flowers and degree of shading as covariables in all partial ordination analyses. We recorded the abundance of flowers for each trap during the regular collection of samples, obtaining four values according to the estimated number of flowers within a $5 \mathrm{~m}$ diameter circle around a trap. The categories of abundance were: $<10$ flowers (1), 10-100 fl. (2), 100-1000 fl. (3), > 1000 fl. (4). There were three categories of shading based on the distance of each trap from a belt of trees, from low (1) through medium (2) to high (3). In addition, the distances from each type of linear element were included as covariables in the analyses of the effect of management, and man- agement was included as covariable when determining the role of local landscape structure. All covariables were selected using forward selection.

\section{Functional diversity analyses}

We calculated functional diversity (FD) using indices of the three fundamental components of FD (sensu Mason et al., 2005; Mouchet et al., 2010): (a) Functional richness - which indicates the amount of functional space occupied by a species of a given assemblage; (b) Functional evenness - which describes how regularly species abundances are distributed in functional space. (c) Functional divergence - which defines how far high species abundances extend from the centre of functional space (Mouchet et al., 2010). We analyzed the FD of the beetle community in relation to mowing only, since the previous GLM revealed very weak responses to grazing (see Table 1). The other two groups were excluded from these analyses as their representatives are too similar to each other in terms of the functional traits measured (e.g., all bumblebees are comparable in flight ability, both their larvae and imagoes feed on nectar and pollen; all butterflies consume nectar and their caterpillars are herbivores).

For the calculation of FD we selected the following species traits: trophic group, habitat association and mobility of imagoes (see Appendix 1). Species feeding on nectar and pollen were classified as "nectarivores", those depending predominantly on living plant tissues were categorized as "herbivores" whereas those consuming mainly dead plant litter and/or faeces were categorized as "saprophagous". The category "necrophagous" included mainly carrion-feeding species and "omnivores" species feeding on a broad spectrum of different kinds of food. Moreover, species were divided into 4 groups according to their prevailing occurrence in particular habitats: forest, open habitats, ecotones, mosaic landscapes and euryoecious species (i.e., habitat generalists). Finally, mobility was scaled as: 1 - low (local, sedentary species including all brachypterous beetles), 2 - high (vagile macropterous species, migrants). These functional traits were selected because they characterize a species interaction with and exploitation of an ecosystem. The species-specific characteristics were obtained from: Balthasar (1956), Tesař (1957), Smreczyński (1965, 1966, 1968, 1972), Freude et al. (1966, 1981), Warchalowski (1971, 1973), Read (1977), Thiele (1977), Šustek (1981), Berge Henegouwen (1986), Lindroth (1992), Sláma (1998), Hoebeke et al. (2000), Laibner (2000), Bieńkowski (2001), Hůrka (2005), Stanovský \& Pulpán (2006), Shields et al. (2009), Kubisz \& Švihla (2013) and Miquel \& Vasko (2014).

Using species-specific features and the abundance of each species in a sample we calculated the functional richness, evenness and divergence (function $d b F D$, FD package in R). These indices were calculated for all traps in areas with the same level of "mowing effect" (i.e., 1-0.5-0.25-0, as the effect of mowing decreased over time) pooled together. Using the same pooled data we constructed regression models of functional groups and their associations with mowing. Associations of the species richness of each functional group with a particular level of mowing was divided by the total species richness of a given functional group at all levels of mowing. This should standardize the final values of species richness among the different functional groups to a particular level of mowing. Square root transformation was used to normalize the distribution of the residuals.

\section{Statistical analyses}

We used ordination to investigate the association of invertebrate community structure with the different management measures and landscape components. Ordination analyses were conducted using CANOCO (version 4.5.); the length of the gradients in 


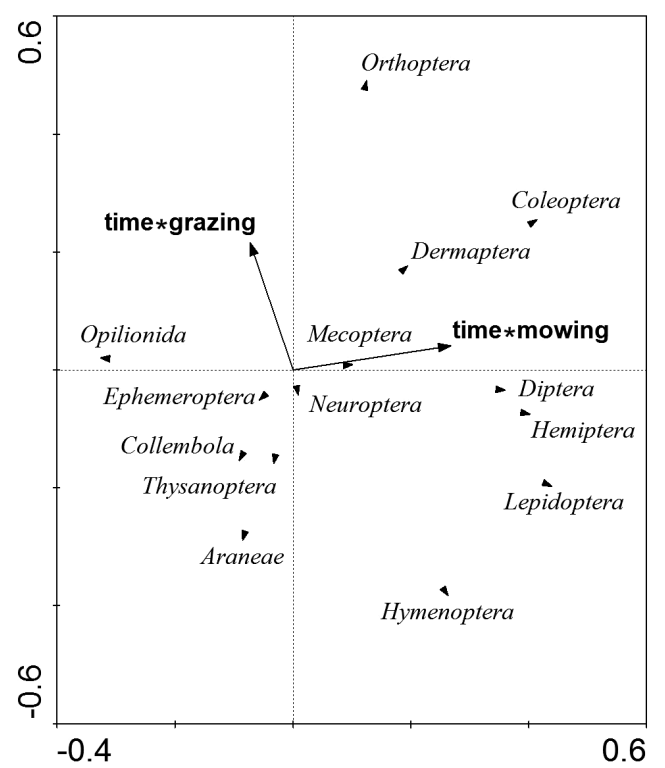

Fig. 2. Biplot CCA of the association of the relative abundance of grassland arthropods (orders) with management variables tested in interaction with time (time*mowing and time*grazing). Only the orders with a total abundance $>100$ individuals were included in this analysis.

species data was determined either by canonical correspondence analysis (CCA; the longest gradient $>4$ ) or redundancy analysis (RDA; the longest gradient $<3$ ) (sensu Ter Braak \& Šmilauer, 2002). These were computed in order to relate gradients in species composition and abundances to external predictors and determine the importance of these predictors. Data on abundances of individuals of the species/orders were log-transformed. We tested the models using the Monte-Carlo permutation test (2000 permutations with split-plot design restricted to linear transects with the aim to ensure an independence of repeated collections from the same traps). Forward selection was used to test environmental variables. The interactions of the explanatory variables mowing and grazing over time were tested. Covariates included time, flower abundance and degree of shading and were selected also by forward selection.

Furthermore, generalized linear models (GLM) with Poisson distributions were used to assess the effect of a particular factor (i.e., "mowing", "strips of grass" and "belts of trees") on the abundance of particular orders and abundances of the species in the targeted groups. In the FD analyses, the relationship between the representation of a particular ecological trait or FD as response variables and the effect of mowing were determined using a generalized linear model with a Gaussian error distribution and $\log$ link function. Standard errors were corrected using the quasilikelihood function. Effects of each explanatory variable were tested also using its quadratic transformation. Step-wise selection based on the lowest Akaike information criterion (AIC) was used to choose the best transformation function for each explanatory variable. We used an F-test to determine the significance of each variable since it is a robust test for over-dispersed data.

Rarefaction curves were constructed to show how species richness or number of orders changes at the sites managed for at least 5 consecutive years using different treatments. Function rarefy (part of the vegan package in R software) computed the expected species richness, or number of orders, and their standard error in random subsamples of a particular sample size.

Data were analyzed using Canoco, v. 4.5 (Ter Braak \& Šmilauer, 2002) and R software (R Development Core Team, 2011).

\section{RESULTS}

The total number of individuals collected was 134,411, consisting of 16 orders of insects and four taxa of other arthropods. We included the following orders in the analyses, with the total number of individuals sampled in parentheses: Araneae $(3,779)$, Coleoptera $(6,342)$, Collembola (243), Dermaptera $(1,093)$, Diptera $(78,023)$, Ephemeroptera (449), Hemiptera $(20,969)$, Hymenoptera $(9,644)$, Lepidoptera $(3,119)$, Mecoptera $(4,699)$, Neuroptera (118), Opilionida $(1,967)$, Orthoptera $(2,476)$ and Thysanoptera $(1,271)$. Other taxa (i.e., Acari, Blattodea, Odonata, Plecoptera, Psocoptera and Trichoptera) were not included be-

TABLE 1. Immediate associations of invertebrate taxa to mowing and grazing predicted by GLM (with pooled numbers of individuals within taxa as dependent variables and two management treatments, mowing and grazing, as explanatory variables). Taxa were categorized on the basis of their mobility. Highly mobile taxa included were mostly the species that can fly and the less mobile group included mainly wingless taxa. The P-values of the factors that are significantly associated with particular taxa are in bold.

\begin{tabular}{|c|c|c|c|c|c|c|c|c|c|}
\hline \multirow{3}{*}{ Dispersal taxon } & & \multicolumn{4}{|c|}{ Mowing } & \multicolumn{4}{|c|}{ Grazing } \\
\hline & & \multicolumn{2}{|c|}{ Regression coefficient } & \multirow{2}{*}{$\mathrm{F}$} & \multirow{2}{*}{$\mathrm{P}$} & \multicolumn{2}{|c|}{ Regression coefficient } & \multirow{2}{*}{$\mathrm{F}$} & \multirow{2}{*}{$\mathrm{P}$} \\
\hline & & $\mathrm{B}$ & $\mathrm{B}^{2}$ & & & $\mathrm{~B}$ & $\mathrm{~B}^{2}$ & & \\
\hline \multirow{9}{*}{ Highly mobile } & Coleoptera & 0.96 & & 53.13 & $<0.001$ & 0.07 & & 0.04 & 0.15 \\
\hline & Diptera & 0.37 & & 22.47 & $<0.001$ & -0.04 & & 0.45 & 0.17 \\
\hline & Ephemeroptera & -8.25 & & 2.00 & 0.16 & -7.64 & & 0.16 & 0.31 \\
\hline & Hemiptera & -1.36 & 1.78 & 6.26 & $<0.01$ & 0.25 & & 0.61 & 0.43 \\
\hline & Hymenoptera & 1.00 & -0.99 & 3.62 & $<0.05$ & -0.49 & & 3.21 & 0.07 \\
\hline & Lepidoptera & 0.25 & & 1.46 & 0.23 & -0.85 & & 1.75 & 0.18 \\
\hline & Mecoptera & 0.11 & & 0.10 & 0.25 & -1.20 & & 0.99 & 0.32 \\
\hline & Neuroptera & -0.88 & & 0.16 & 0.31 & -4.30 & & 0.12 & 0.27 \\
\hline & Orthoptera & -2.38 & 2.31 & 4.19 & $<0.01$ & 1.24 & & 1.13 & 0.30 \\
\hline \multirow{4}{*}{ Less mobile } & Araneae & -0.45 & & 2.15 & 0.14 & -1.96 & & 3.03 & 0.08 \\
\hline & Collembola & -25.84 & & 6.20 & $<0.05$ & -6.03 & & 0.40 & 0.47 \\
\hline & Dermaptera & -0.02 & & $<0.001$ & $<0.05$ & 0.45 & & 0.01 & 0.24 \\
\hline & Opilionida & -0.97 & & 11.75 & $<0.001$ & 0.47 & & 1.13 & 0.30 \\
\hline
\end{tabular}




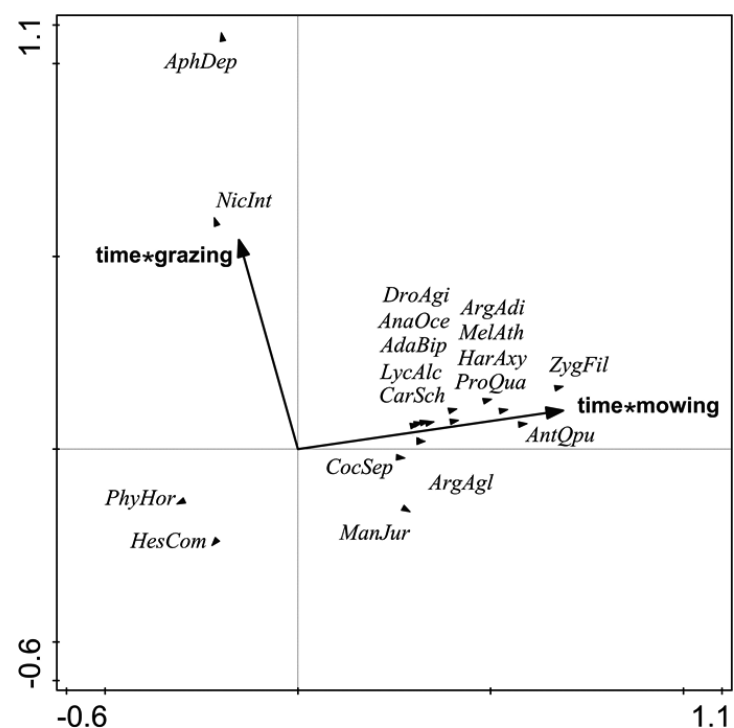

Fig. 3. Biplot RDA of the association of the relative abundance of species with management variables tested in interaction with time (time*mowing and time*grazing). Only species with a fit-range $>1 \%$ are depicted in the ordination diagram. Names of species are denoted by triangles with acronyms: Adalia bipunctata (AdaBip), Anatis ocellata (AnaOce), Aphodius depressus (AphDep), Argynnis adippe (ArgAdi), Argynnis aglaja (ArgAgl), Anthaxia quadripunctata (AntQpu), Carabus scheidleri (CarSch), Coccinella septempunctata (CocSep), Dromius agilis (DroAgi), Harmonia axyridis (HarAxy), Hesperia comma (HesCom), Lycaena alciphron (LycAlc), Maniola jurtina (ManJur), Melitaea athalia (MelAth), Nicrophorus interruptus (NicInt), Phyllopertha horticola (PhyHor), Propylea quatuordecimpunctata (ProQua), Zygaena filipendulae (ZygFil).

TABLE 2. The immediate associations of individual species of the target groups with mowing predicted by GLM (with pooled numbers of individuals within species as dependent variables). We included only species with total abundance $\geq 5$ and with statistically significant or nearly significant associations. Species with significant associations with mowing have their P-values and regression coefficients in bold.

\begin{tabular}{lrllrr}
\hline Species & \multicolumn{1}{c}{ N } & F & P & \multicolumn{1}{c}{ B } & \multicolumn{1}{c}{ AIC } \\
\hline Aglais urticae & 29 & 3.51 & 0.06 & -2.76 & 231.52 \\
Anthaxia quadripunctata & 82 & $18.21<\mathbf{0 . 0 0 1}$ & $\mathbf{2 . 8 9}$ & 253.70 \\
Argynnis adippe & 7 & 4.80 & $\mathbf{0 . 0 3}$ & $\mathbf{2 . 1 4}$ & 72.83 \\
Argynnis aglaja & 21 & 6.06 & $\mathbf{0 . 0 1}$ & $\mathbf{1 . 6 9}$ & 186.04 \\
Cantharis fusca & 21 & 0.01 & 0.07 & -4.02 & 218.77 \\
Gonepteryx rhamni & 5 & 0.01 & 0.08 & 0.17 & 59.94 \\
Harmonia axyridis & 5 & 4.61 & $\mathbf{0 . 0 3}$ & $\mathbf{2 . 3 5}$ & 58.14 \\
Hesperia comma & 153 & 6.12 & $\mathbf{0 . 0 1}$ & $-\mathbf{- 1 . 4 1}$ & 783.28 \\
Lycaena hippothoe & 306 & 4.27 & $\mathbf{0 . 0 4}$ & $\mathbf{0 . 6 7}$ & 1432.96 \\
Lycaena tityrus & 16 & 4.94 & $\mathbf{0 . 0 3}$ & $-\mathbf{2 4 . 5 8}$ & 146.42 \\
Nicrophorus vespillo & 164 & 0.01 & 0.08 & 0.06 & 1070.41 \\
Oedemera virescens & 16 & 0.01 & 0.06 & 0.08 & 145.82 \\
Poecilus cupreus & 41 & 3.53 & 0.06 & -2.65 & 323.00 \\
Phyllopertha horticola & 151 & 5.38 & $\mathbf{0 . 0 2}$ & $-\mathbf{- 3 . 3 9}$ & 1059.61 \\
Propyleaquatuordecimpunctata & 7 & 6.23 & $\mathbf{0 . 0 1}$ & $\mathbf{2 . 3 1}$ & 71.52 \\
Serica brunnea & 11 & 0.01 & $\mathbf{0 . 0 2}$ & $\mathbf{0 . 0 3}$ & 120.31 \\
Silpha obscura & 56 & 0.01 & $\mathbf{0 . 0 5}$ & $\mathbf{0 . 0 8}$ & 522.49 \\
Thanatophilus sinuatus & 70 & 0.00 & $\mathbf{0 . 0 1}$ & $\mathbf{0 . 0 1}$ & 551.78 \\
Vanessa cardui & 138 & 6.82 & $\mathbf{0 . 0 1}$ & $-\mathbf{2 . 2 0}$ & 802.61 \\
\hline
\end{tabular}
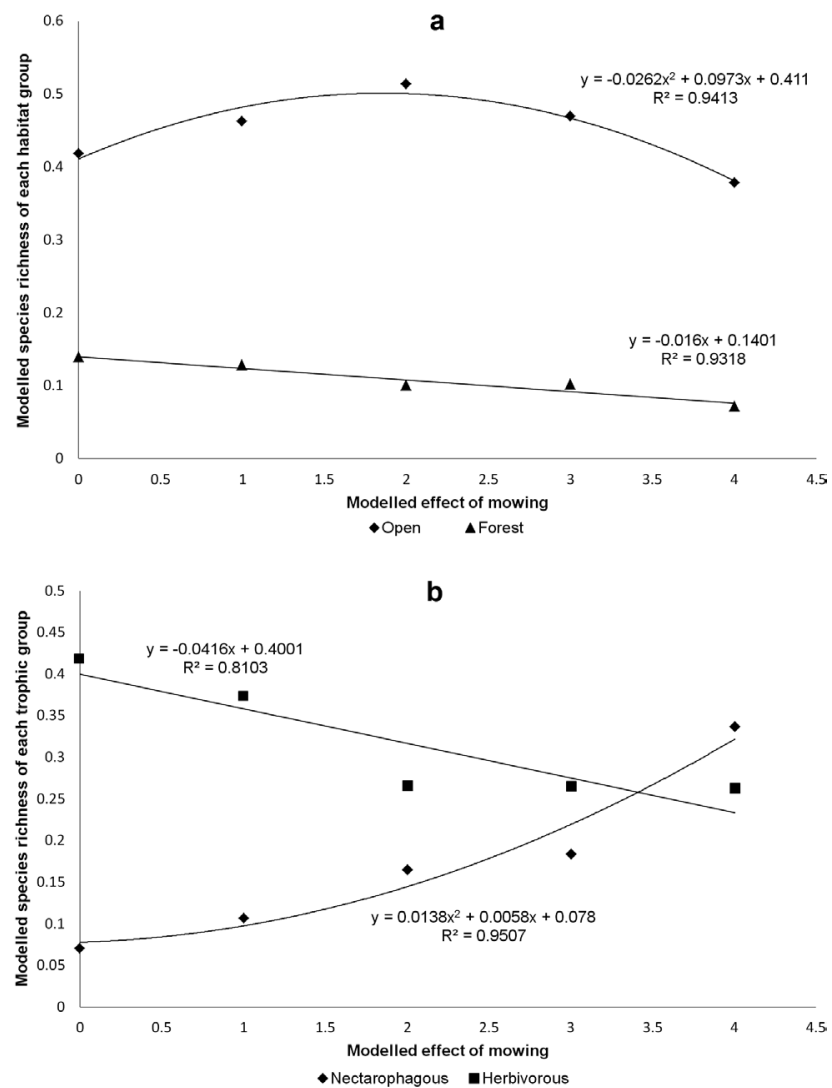

Fig. 4. Modelled association of standardized species richness with mowing for (a) habitats and (b) trophic functional groups of beetles predicted by generalized linear model using a gaussian error distribution and log link function. Species richness of each functional group in samples from particular mowing treatments was standardized by total species richness of given functional group recorded at all intensities of mowing. Only the significant responses of functional groups are depicted.

cause fewer than 100 individuals were collected, which indicates an accidental occurrence of these taxa.

\section{Associations with different management practices}

The associations of different taxonomic levels, orders and species, with the different types of management were determined. The effect of management was also studied at two different time scales, immediately after a particular type of management in a given year, and for each of the four management treatments that have operated for at least five years.

\section{Immediate effects of managing grassland}

Fig. 2 shows the results of the ordination analysis of the immediate effect on the abundances of particular taxa of two management practices tested in interaction with time. The structure of the arthropod communities at the study sites that were mown and grazed differed (Table 1), with a significant effect of time*mowing $(\mathrm{F}=12.80, \mathrm{P}=0.022)$. The gradient along the horizontal canonical axis corresponds to the mobility of the taxa (Fig. 2). The most mobile taxa are mainly on the right hand side of the diagram (Diptera, Lepidoptera, Hemiptera and Coleoptera), whereas 
a) Orders

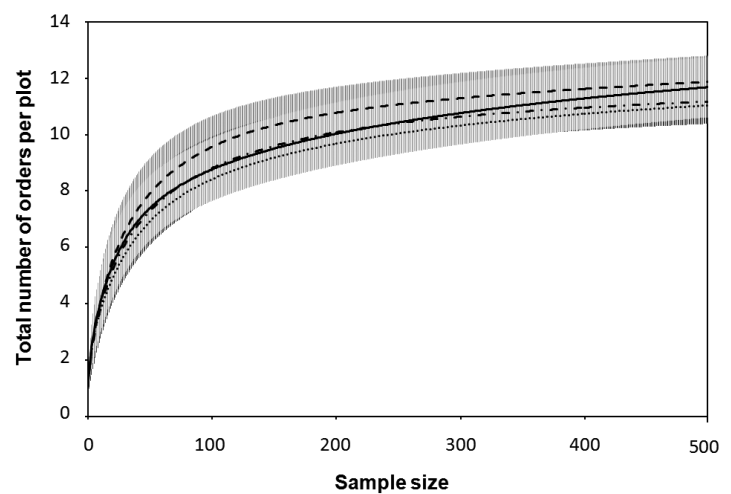

c) Bumblebees

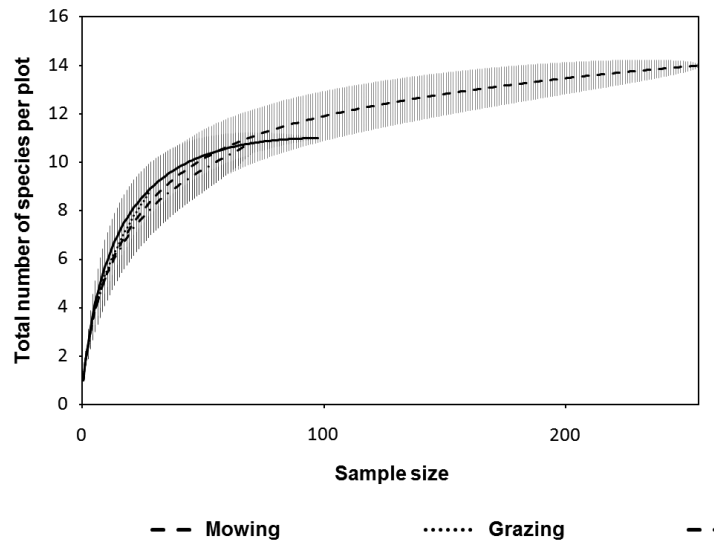

b) Butterflies

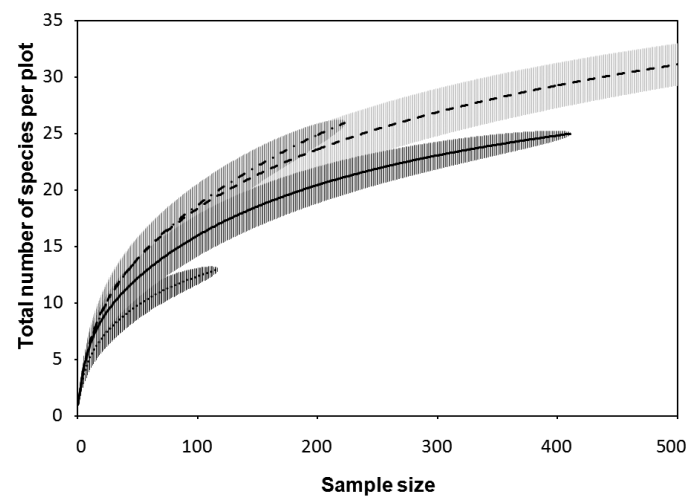

d) Beetles

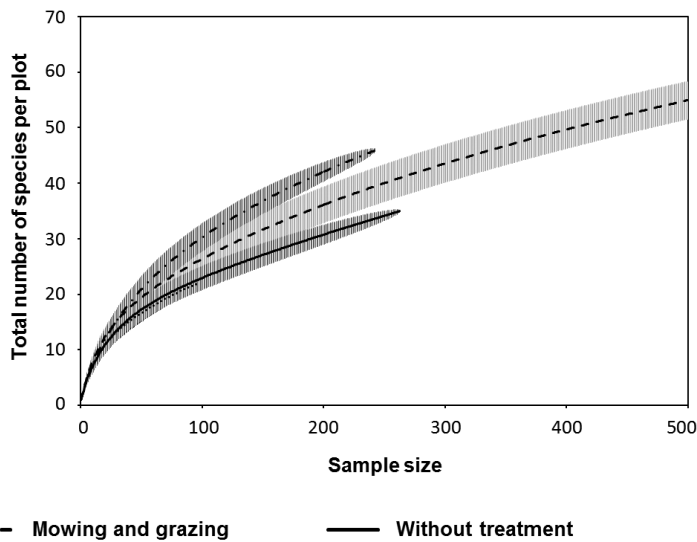

Fig. 5. Total number of taxa (a) and number of species of the targeted groups (b, c, d) recorded in patches subjected to specific management treatments for at least five consecutive years. The error bars depicted for each rarefaction curve represent standard errors.

the wingless surface-active groups are on the left hand side (Opilionida, Araneae and Collembola).

Additional GLM analyses supported the hypothesis that more mobile taxa, such as Mecoptera and Neuroptera, might not be greatly affected by disturbance due to either mowing or grazing. Other mobile groups such as Diptera, Coleoptera and Hymenoptera may even be found in higher numbers in samples collected from cut sward (Table 1). In contrast, more sedentary, flightless taxa (Collembola, Opilionida, Dermaptera) significantly tended to be collected mainly in plots with undisturbed vegetation (Table 1). None of arthropod taxa were significantly associated with cattle grazing (Table 1).

Subsequently, we analyzed the associations with both mowing and grazing in interaction with time at the species level using RDA (Fig. 3). Similar to the previous analysis, the structure of the insect community was significantly associated with time*mowing $(\mathrm{F}=2.41, \mathrm{P}=0.001)$, whereas the association of species abundances with time*grazing was weak and inconclusive $(\mathrm{F}=0.97, \mathrm{P}=0.502)$. Interestingly, the majority of species seemed to benefit from mowing (Fig. 3, Table 2).

As the previous analyses revealed that the community structure of arthropods was associated with the recent mowing event, we included it as the main factor in the analyses of functional diversity of beetles. Our results revealed a significant increase in functional divergence at re- cently mowed sites compared to places with tall grass $(\mathrm{F}=$ $5.88, \mathrm{P}=0.026$ ). Unlike functional divergence, functional evenness and richness did not change significantly along the gradient of mowing ( $\mathrm{F}=0.00, \mathrm{P}=0.9795 ; \mathrm{F}=3.48$, $\mathrm{P}=0.059$ ).

Furthermore, we analyzed the changes in the proportion of particular functional groups of beetles with increase in the intensity of mowing. Forest species were negatively associated with mowing $(\mathrm{P}<0.001)$. In contrast, species associated with open habitats were more abundant in medium-grown swards than in full-grown and recently mown vegetation ( $\mathrm{P}=0.002)$ (Fig. 4a). Mowing is associated with a decrease in the number of herbivorous taxa in samples $(\mathrm{P}<0.001)$, whereas that of nectarivores increased $(\mathrm{P}<$ 0.001) (Fig. 4b).

\section{Effects of long-term management}

Rarefaction curves showed that the number of orders and bumblebee species did not differ substantially in the different management treatments, but the lowest number of beetle and butterfly species were recorded in grazed patches and those not managed. In contrast, the maximum species richness of both groups was recorded at sites that were either mown or mown and grazed (Fig. 5).

\section{The role of linear landscape features}

The final aim of our study was to determine the association of the community structure of arthropods with linear 
landscape features, such as strips of grass and belts of trees (see above). Therefore, we first constructed a GLM based on an ordination of the numbers of representatives of all the orders as a response variable. This revealed significant associations for the majority of the groups investigated, which were mainly positively associated with both belts of trees and strips of grass, in other words, the abundances of most orders increased the closer they were collected to either of these linear landscape features (Table 3).

Second, we concentrated on the association of the abundances of particular species of the targeted groups with belts of trees and strips of grass. Whereas the majority of butterfly species tended to be most abundant close to both types of boundaries, many species of beetles increased in numbers towards the centre of meadows. The associations of species of bumblebees were mixed (Figs 6a, b, c).

\section{DISCUSSION AND CONCLUSIONS}

\section{Associations with grassland management}

Our results have shown that although the associations of the different taxa of grassland arthropods with grassland management differed, there is a general pattern (Fig. 2). Less mobile groups, especially those unable to fly, such as Opilionida, Collembola and Araneae, were negatively associated with mown areas (Fig. 2, Table 1). These groups might be strongly affected by mowing because of its direct effect on their survival (Humbert et al., 2010, 2012) and the quality of the habitat, due to their limited mobility compared to winged groups. In contrast, the abundance of some highly mobile groups (Coleoptera, Diptera, and Lepidoptera) tended to increase in cut areas (Fig. 2, Table 1). This trend was apparent also at the species-level (Fig. 3, Table 2) as all taxa assessed belong to winged groups, with only a few exceptions in the Coleoptera (e.g., some Carabidae and Curculionidae). We suggest the following explanations for this trend:
First, mowing immediately depletes the majority of the food sources (Cizek et al., 2012). Simultaneously, the taxa that showed a positive association with mowing belonged mainly to groups consisting of highly mobile species. A depleted food supply may drive the mobile species to seek more suitable patches with plentiful resources (Hossain et al., 2002). Due to an increase in movements within the area the probability of "being caught" may increase.

Second, the attractiveness of YPWT probably increases after the removal of flowering plants (Wilson et al., 2008). This explanation is also supported by the results of the functional trait analysis, which revealed a significant increase in the species richness of nectarophagous beetles at recently mown, i.e., flowerless sites (Fig. 4b). In contrast, the total species richness of herbivorous beetles significantly decreased (Fig. 4b), which is a consequence of the removal of their source of food. For example, the numbers of imagoes of the abundant scarab beetle, Phyllopertha horticola, which feeds mainly on fully-grown vegetation or even shrubs and trees (Bogatko, 1990), decreased at mown sites (Table 2).

The association of species in the target groups with recent mowing is not consistent. Many of the species responded positively to mowing (Table 2). This might be a methodical artefact as the majority of these species are good dispersers.

Unlike mowing, grazing did not have an immediate effect on any of the arthropod taxa (Fig. 2, Table 1). Concurring with Batáry et al. (2007, 2008), we highlight the role of different grazing pressures on the composition of insect communities. As the grazing intensity in our plots was only 0.82 to 0.84 cows/ha, it is likely that this low intensity grazing accounts for the non-significant trends (e.g., a negative association of Araneae and Hymenoptera with grazing - see Table 1). Seemingly positive association of the dung beetle Aphodius depressus (Fig. 3) with grazing is most likely due the presence of fresh cattle faeces than a direct effect of grazing on vegetation (Hanski et al., 1987).

TABLE 3. Individual associations of particular taxa of invertebrates associated with grasslands with both types of linear landscape features (belts of trees, strips of grass), predicted by GLM (with pooled numbers of individuals within taxa for each trap as dependent variables and distance of each trap from both types of feature as explanatory variables). Taxa with significant associations with particular lineas structure have their P-values in bold.

\begin{tabular}{|c|c|c|c|c|c|c|c|c|}
\hline \multirow{3}{*}{ Taxon } & \multicolumn{4}{|c|}{ Belts of trees } & \multicolumn{4}{|c|}{ Strips of grass } \\
\hline & \multicolumn{2}{|c|}{ Regression coefficient } & \multirow{2}{*}{$\mathrm{F}$} & \multirow{2}{*}{$\mathrm{P}$} & \multicolumn{2}{|c|}{ Regression coefficient } & \multirow{2}{*}{$\mathrm{F}$} & \multirow{2}{*}{$\mathrm{P}$} \\
\hline & $\mathrm{B}$ & $\mathrm{B}^{2}$ & & & $\mathrm{~B}$ & $\mathrm{~B}^{2}$ & & \\
\hline Araneae & 0.01 & & 23.03 & $<0.001$ & 0.02 & -0.001 & 12.31 & $<0.001$ \\
\hline Collembola & 0.001 & & 0.03 & 0.137 & -0.01 & & 2.17 & 0.14 \\
\hline Coleoptera & 0.01 & & 22.67 & $<0.001$ & -0.01 & 0.001 & 19.65 & $<0.001$ \\
\hline Dermaptera & 0.002 & & 0.158 & 0.31 & -0.003 & & 0.59 & 0.44 \\
\hline Diptera & -0.01 & 0.001 & 10.24 & $<0.001$ & 0.004 & -0.001 & 3.47 & $<0.05$ \\
\hline Ephemeroptera & -0.001 & & 0.001 & $<0.01$ & 0.001 & & 1.17 & 0.28 \\
\hline Hemiptera & 0.01 & -0.001 & 3.84 & $<0.05$ & -0.001 & & 16.14 & $<0.001$ \\
\hline Hymenoptera & -0.01 & & 15.55 & $<0.001$ & 0.001 & & 0.89 & 0.35 \\
\hline Lepidoptera & -0.01 & & 4.76 & $<0.05$ & 0.001 & & 0.23 & 0.37 \\
\hline Mecoptera & -0.001 & & 0.54 & 0.46 & -0.01 & 0.01 & 12.54 & $<0.001$ \\
\hline Neuroptera & -0.02 & & 2.23 & 0.14 & 0.07 & -0.001 & 2.84 & 0.05 \\
\hline Opilionida & 0.01 & -0.001 & 2.72 & 0.07 & 0.03 & -0.001 & 36.63 & $<0.001$ \\
\hline Orthoptera & 0.02 & -0.001 & 11.34 & $<0.001$ & -0.01 & & 64.81 & $<0.001$ \\
\hline
\end{tabular}




\section{Long-term effects of management}

We investigated the effects of four types of management (mowed plots, grazed plots, combination of both and no management during the vegetation period until the end of September) using rarefaction curves. These were constructed in order to determine if there is an association between species richness and number of orders present and type of management at each site. The highest species richness of butterflies and beetles was associated with mowing, especially combined with grazing. In contrast, the lowest number of butterfly species was recorded at patches managed by a single grazing regime, followed by patches not managed during the vegetative season. Although the effects of grazing and absence of management were indistinguishable in terms of beetles, both of these treatments are similarly associated with low numbers of species (Fig. 5 ). We stress that a comparatively higher number of species of beetles and butterflies is associated with the combined regime of mowing and grazing than grazing alone (Fig. 5). Our explanation for this trend is that the intensity of grazing at the sites was very low ( 0.82 and 0.84 cattle/ ha). Cattle did not graze the whole area, thus many patches of vegetation were ungrazed. This may have resulted in a slow change in plant composition (Matějková et al., 2003) towards lower numbers of competitive species, which affected the invertebrate communities. Such a trend might not be seen for years after implementing this treatment. In accordance with this interpretation are the results of the rarefaction for sites subjected to both grazing and cutting in each season. Higher numbers of species were associated with this treatment than just grazing. Under a low grazing pressure, competitive plants (i.e., mainly grasses), which benefit from low intensity grazing are probably suppressed by mowing. This may ensure more diversified vegetation and also more heterogeneous arthropod communities than those found at grazed sites.

Comparable suitability of mowing from a long-term point of view can be interpreted as follows: Most of the individuals collected belonged to species associated with treeless habitats, which are strongly dependent on disturbance of natural succession resulting in the formation of forest (Konvicka et al., 2008). Low intensity mowing, i.e., once per annum, varied in time and space, is a suitable long-term type of management (Rundlof et al., 2008; Cizek et al., 2012). Although mowing immediately decreases the abundance of insects, (Humbert et al., 2009, 2010) it is nevertheless a reliable means of suppressing both trees and competitive species of plants, which are often dominant grasses (Gibson, 2009). This results in the increase in the diversity of plants, including flowering dicotyledons, which together with the diverse architecture of the plants (Strong et al., 1984; Haysome \& Coulson, 1998; EspíritoSanto et al., 2007) probably support a greater diversity of various guilds of insects (Hutchinson, 1959; Knop et al., 1999). In other words, grassland invertebrates must be adapted to disturbance, which is consistent with the results of the partial analysis of functional diversity based on the habitat associations of the species. Mowing supported a single functional group, open habitat species, although they only reached peak abundances after partial recovery of the swards (Fig. 4a).

\section{Association with particular linear landscape features}

We determined the association of arthropod communities in sub-montane grasslands with two linear landscape features, strips of grass and belts of trees. Based on the GLM the majority of higher taxa tended to occur in higher numbers close to both types of boundaries (Table 3 ), where there may be specific microclimates and sheltered environments for these animals (Maudsley, 2000; Merckx et al., 2009). In contrast, the abundance of beetles and spiders was significantly higher in the centre of the meadows, i.e., furthest from both types of boundary (Table 3). This might be attributed to the trends of the most abundant species being for species that belong to the groups closely associated with open habitats [e.g., beetles: Anthaxia spp., Eschcholtz, 1829; Rhagonycha spp., Eschcholtz, 1830; Oxythyrea funesta - see Fig. 6c and spiders, for instance Xysticus spp., C.L. Koch, 1835; Pachygnatha degeeri, Sundevall, 1830; Pardosa palustris (Linnaeus, 1758)].

Finally, GLM were used to determine the associations of individual species of Lepidoptera, bumblebees and beetles (Figs 6a, b and c). Lepidoptera were strongly and positively associated with both strips of grass and belts of trees at the species level. The majority of butterfly species were recorded close to these linear features, including typical grassland dwellers, such as ringlets Maniola jurtina and Aphantopus hyperanthus (cf. Kulfan et al., 2012), coppers Lycaena virgaureae and L. hippothoe and the skipper Hesperia comma (Fig. 6a). Such a clear association might be interpreted as a consequence of the environment near to the edges being more sheltered with tall vegetation compared to the regularly disturbed area of the meadows (Merckx et al., 2009). Lepidoptera may shelter there from the wind or as a refuge from predation (Merckx et al., 2010). Linear landscape features may also serve as corridors for many species, including butterflies (Davies \& Pullin, 2007) and, finally, an ecotone may be an important refuge where multiple habitats meet (e.g., Downie et al., 1996; Ewers \& Didham, 2006; Vu, 2009).

In contrast, bumblebees were not associated with strips of grass (see Table 2). This may be due to the fact that bumblebees are able to fly even in unfavourable conditions (Goulson, 2010), i.e., low temperatures, windy and even rainy weather, thus they do not need as much shelter as butterflies. Alternatively, this trend may reflect individual demands of each species for nesting sites and flowers as sources of nectar and pollen (Connop et al., 2010), which might account for the trends in the abundance of particular species (Fig. 6b).

\section{Conservation summary}

This study was carried out in a submontane treeless area managed for at least five years by the Czech AES. The grasslands at this study site are lightly grazed and cautiously mown. The farmer adopted some of the above-standard measures of the Czech AES (i.e., gradual mowing of par- 

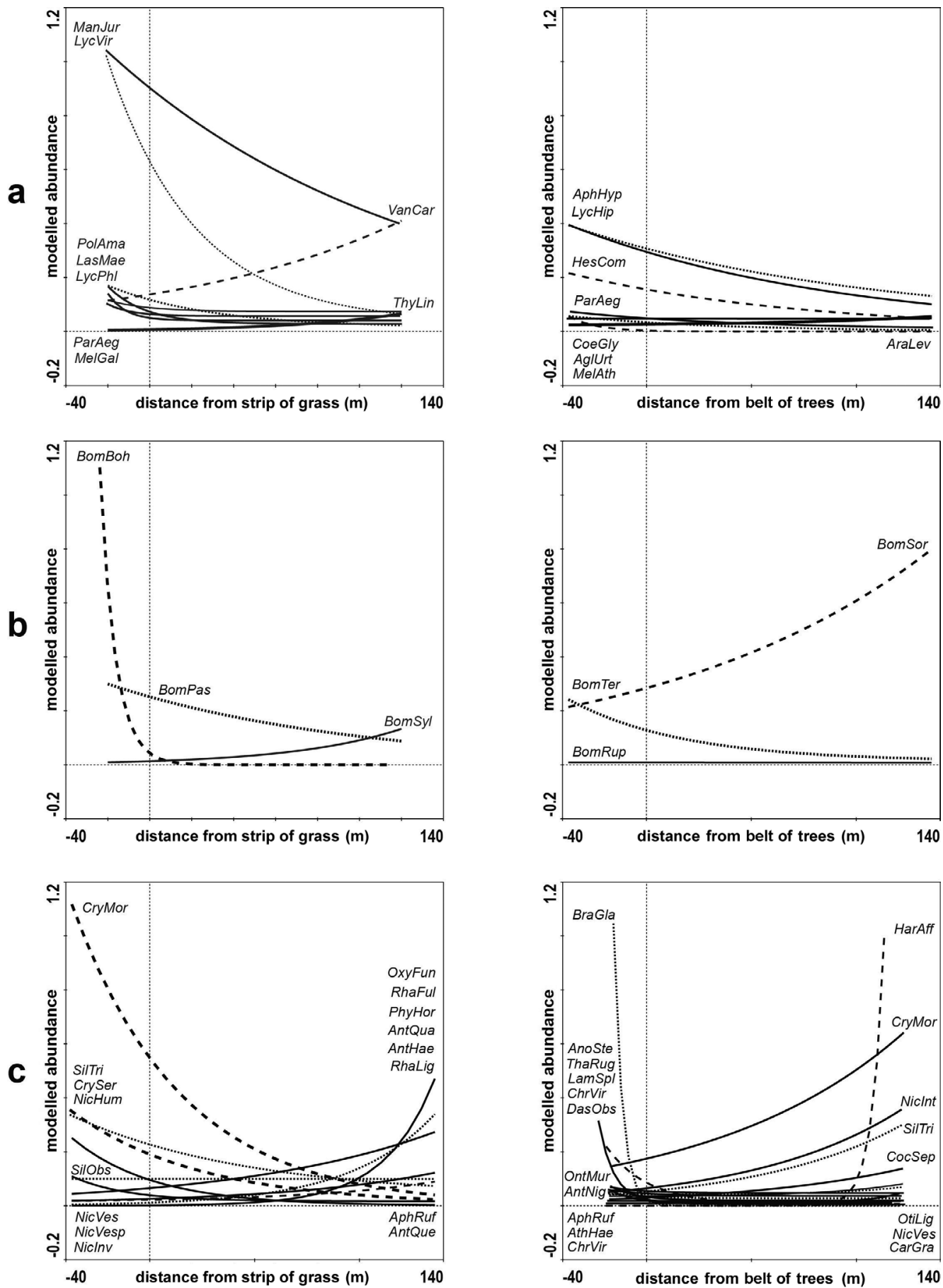

Fig. 6. Individual associations of species of butterflies (a), bumblebees (b) and beetles (c) with strips of grass and belts of trees predicted by GLM (with numbers of individuals of each species pooled for each trap as dependent variables and distance of each trap from both types of boundary as explanatory variables). Only species significantly associated with each boundary are listed. The dominance of the different species of beetles follows Tischler (1949) (i.e., $\mathrm{E}=$ eudominant, $\mathrm{D}=$ dominant, $\mathrm{S}=$ subdominant, $\mathrm{R}=$ recedent, $\mathrm{SR}=$ subrecedent species ). Acronyms for the species with positive associations with strips of grass / belts of trees are placed on the left hand side of the figures, acronyms of species negatively associated with strips of grass / belts of trees are situated on right hand side. Responses of particular species are denoted by curves with following abbreviations: (a) Aglais urticae (AglUrt), Aphantopus hyperantus (AphHyp), Araschnia levana (AraLev), Coenonympha glycerion (CoeGly), Hesperia comma (HesCom), Lasiommata maera (LasMae), Lycaena hippothoe (LycHip), Lycaena phlaeas (LycPhl), Lycaena virgaureae (LycVir), Maniola jurtina (ManJur), Melanargia galathea (MelGal), Melitaea athalia (MelAth), Pararge aegeria (ParAeg), Polyommatus amandus (PolAma), Thymelicus lineola (ThyLin), Vanessa cardui (VanCar); (b) Bombus bohemicus (BomBoh), Bombus pascuorum (BomPas), Bombus terrestris (BomTer), Bombus soroeensis (BomSor), Bombus sylvarum (BomSyl), Bombus rupestris (BomRup); (c) Anoplotrupes stercorosus (AnoSte) - R, Anthaxia quadripunctata (AntQua) - S, Anthaxia quercata (AntQue) - SR, Antherophagus nigricornis (AntNig) - SR, Aphodius rufipes (AphRuf) - SR, Athous haemorrhoidalis (AthHae) - SR, Brachypterus glaber (BraGla) - SR, Carabus granulatus (CarGra) - SR, Coccinella septempunctata (CocSep) - S, Cryptocephalus moraei (CryMor) - D, Cryptocephalus sericeus (CrySer) - E, Chrysanthia viridissima (ChrVir) - SR, Chrysolina fastuosa (ChrFas) - SR, Dasytes obscurus (DasObs) SR, Harpalus affinis (HarAff) - SR, Lamprohiza splendidula (LamSpl) - SR, Nicrophorus interruptus (NicInt) - SR, Nicrophorus investigator (NicInv) - SR, Nicrophorus humator (NicHum) - SR, Nicrophorus vespillo (NicVes) - D, Nicrophorus vespilloides (NicVesp) - S, Ontholestes murinus (OntMur) - SR, Otiorhynchus ligustici (OtiLig) - SR, Oxythyrea funesta (OxyFun) - D, Phyllopertha horticola (PhyHor) - D, Rhagonycha fulva (RhaFul) - S, Rhagonycha lignosa (RhaLig) - SR, Silpha obscura (SilObs) - S, Silpha tristis (SilTri) - S, Thanatophilus rugosus (ThaRug) - SR. 
ticular blocks and strips left uncut for the whole vegetation season). Despite this purportedly benign agricultural management, we recorded significant associations with mowing. Over a short time-scale, the less mobile taxa, which are unable to fly, were negatively associated with mowing. In contrast, in the long-term the highest species richness of butterflies and beetles was associated with mowing once per year, especially when combined with grazing. In addition, the structure of the arthropod communities was substantially associated with both types of boundaries, i.e., strips of grass and narrow belts of trees. The majority of the groups studied were positively associated with these linear features. Therefore, based on our results and the findings of other recent studies (e.g., Merckx et al., 2009, 2010; Fabriciusová et al., 2011; Cizek et al., 2012; Humbert et al., 2012; etc.) we recommend:

(i) As the time of mowing was an important determinant of the presence of certain grassland invertebrates in the short-term, we emphasize the key role of the timing of this treatment. The maximum abundances of invertebrates were recorded in July, this therefore is the worst time to mow similar sub-montane meadows. Nevertheless, we sampled mainly only adults. Therefore, immobile larval stages (usually more sensitive to disturbances caused by mowing and grazing) are most abundant earlier in the season. Thus we recommend postponement of mowing to the second half of July. Moreover, the whole area should not be mown at the same time but in two stages to ensure that only half of the sward is disturbed at each mowing;

(ii) In addition, uncut strips left until the beginning of the next vegetation season may help mitigate the negative effects of mowing;

(iii) Most of the grassland arthropods may be associated with these strips if they are located along permanent landscape features such as grass strips and belts of trees. In addition, the association with boundaries were generally positive, possibly due to the greater heterogeneity of vegetation there (Hansen \& Castri, 1992);

(iv) The establishment of linear landscape features such as belts of trees and strips of permanent grass can substantially increase the biological value of agroecosystems (e.g., Balmer \& Erhardt, 2000; Baur et al., 2006; Kulfan et al., 2012) in Central European farmland, recently affected by agricultural intensification.

ACKNOWLEDGEMENTS. We are very grateful to F. Trnka and R. Gabriš for identifying the beetles and to J. Stanovský for help with coleopteran characteristics necessary for the analyses of functional diversity. V. Smetana deserves many thanks for identifying bumblebees and helpful comments on their ecology. We are much obliged to I. Pur, the nature-friendly-thinking owner of the farmland where the survey took place. V. Marková, A. Gouveia and A.F.G. Dixon kindly checked our English. Last but not least we thank anonymous reviewers and the associate editor (J. Beck) for many valuable suggestions and comments which substantially improved our manuscript. Funding for the research project was provided by the Ministry of the Environment of the Czech Republic (VaV SP/2D3/155/08).

\section{REFERENCES}

Andersen A.N. 1995: Measuring more of biodiversity: genus richness as a surrogate for species richness in Australian ant faunas. - Biol. Conserv. 73: 39-43.

Balmer O. \& Erhardt A. 2000: Consequences of succession on extensively grazed grasslands for Central European butterfly communities: rethinking conservation practises. - Conserv. Biol. 14: 746-757.

Balthasar V. 1956: [Lamellicorn Beetles - Lamellicornia. Vol. 1. Lucanidae - Stag Beetles, Scarabaeidae - Scarab Beetles. Pleurosticti.] Fauna of Czechoslovakia 8. Czechoslovak Academy of Sciences, Praha, 287 pp. [in Czech, German and Russian abstr.].

BATÁRY P., BÁLdi A. \& ERdös S. 2007: Grassland versus nongrassland bird abundance and diversity in managed grasslands: local, landscape and regional scale effects. - Biodivers. Conserv. 16: 871-881.

Batáry P., BÁldi A., SAmu F., Szüts T. \& Erdös S. 2008: Are spiders reacting to local or landscape scale effects in Hungarian pastures? - Biol. Conserv. 141: 2062-2070.

Baur B., Cremene C., Groza G., Rakosy L., Schileyko A., Baur A., Stoll P. \& Erhardt A. 2006: Effects of abandonment of subalpine hay meadows on plant and invertebrate diversity in Transylvania, Romania. - Biol. Conserv. 132: 261-273.

Benton T.G., Vickery J.A. \& WiLson J.D. 2003: Farmland biodiversity: is habitat heterogeneity the key? — Trends Ecol. Evol. 18: $182-188$.

Berge Henegouwen A. 1986: Revision of the European species of Anacaena. — Entomol. Scand. 17: 393-407.

Biaggini M., Consorti R., Dapporto L., Dellacasa M., Paggetti E. \& Corti C. 2007: The taxonomic level order as a possible tool for rapid assessment of Arthropod diversity in agricultural landscapes. - Agr. Ecosyst. Environ. 122: 183-191.

BIEŃKOwsKi A.O. 2001: A study on the genus Chrysolina Motschulsky, 1860, with a checklist of all the described subgenera, species, subspecies and synonyms (Coleoptera: Chrysomelidae: Chrysomelinae). — Genus 12: 105-235.

Blades D.C.A. \& Marshall S.A. 1994: Terrestrial arthropods of Canadian peatlands: Synopsis of pan trap collections at four southern Ontario peatlands. In Finnamore A.T. \& Marshall S.A. (eds): Terrestrial Arthropods of Peatlands, with Particular Reference to Canada. Symposium Volume on Peatland Arthropods. - Mem. Entomol. Soc. Can. 169: 221-284.

BogatKo W. 1990: Food preference of ornamental poplars and willows of Phyllopertha horticola L. and Melasoma vigintipunctatum Scop., Coleoptera. — Pol. Pis. Entomol. 60: 205210.

BoITEAU G. 1990: Effect of trap color and size on relative efficiency of water-pan traps for sampling alate aphids (Homoptera: Aphididae) on potato. — J. Econ. Entomol. 83: 937-942.

Buri P., Humbert J.-Y. \& Arlettaz R. 2014: Promoting pollinating insect in intensive agricultural matrices: Field-scale experimental manipulation of hay-meadow mowing regimes and its effects on bees. — PLoS ONE 9(1): e85635.

Cadott M.W., Carscadden K. \& Mirotchnick N. 2011: Beyond species: functional diversity and the maintenance of ecological processes and services. — J. Appl. Ecol. 48: 1079-1087.

Cameron S.A., Hines H.M. \& Williams P.H. 2007: A comprehensive phylogeny of the bumble bees (Bombus). — Biol. J. Linn. Soc. 91: 161-188.

Campbell J.W. \& Hanula J.L. 2007: Efficiency of Malaise traps and coloured pan traps for collecting flower visiting insects from three forested ecosystems. — J. Insect Conserv. 11: 399408 . 
Cizek O., Zamecnik J., Tropek R., Kocarek P. \& Konvicka M. 2012: Diversification of mowing regime increases arthropods diversity in species-poor cultural hay meadows. - J. Insect Conserv. 16: 215-226.

Connop S., Hill T., Steer J. \& Shaw P. 2010: The role of dietary breadth in national bumblebee (Bombus) declines: Simple correlation? - Biol. Conserv. 143: 2739-2746.

Davies Z.G. \& Pullin A.S. 2007: Are hedgerows effective corridors between fragments of woodland habitat? An evidence-based approach. - Landsc. Ecol. 22: 333-351.

Davies K.F., Chesson P., Harrison S., Inouye B.D., Melbourne B.A. \& Rice K.J. 2005: Spatial heterogeneity explains the scale dependence of the native-exotic diversity relationship. - Eco$\log y$ 86: $1602-1610$

DeBAno S. 2006: Effects of livestock grazing on aboveground insect communities in semi-arid grasslands of southeastern Arizona. - Biodiv. Conserv. 15: 2547-2564.

Downie I.S., Coulson J.C. \& Butterfield E.L. 1996: Distribution and dynamics of surface-dwelling spiders across a pastureplantation ecotone. - Ecography 19: 29-40.

Duffey E., Morris M.G., Sheail J., Ward L.K., Wells D.A. \& Wells T.C.E. 1974: Grassland Ecology and Wildlife Management. Chapman \& Hall, London, 320 pp.

Ekroos J., Heliölä J. \& KuUssaAri M. 2010: Homogenization of lepidopteran communities in intensively cultivated agricultural landscapes. - J. Appl. Ecol. 47: 459-467.

Espírito-Santo M.M., de S. Neves F., Andrade-Neto F.R. \& FerNANDES G.W. 2007: Plant architecture and meristem dynamics as the mechanisms determining the diversity of gall-inducing insects. - Oecologia 153: 353-364.

Evans E.W. \& Bailey K.W. 1993: Sampling grasshoppers (Orthoptera: Acrididae) in Utah grasslands: pan trapping versus sweep sampling. - J. Kans. Entomol. Soc. 66: 214-222.

EwERS R.M. \& Didham R.K. 2006: Continuous response functions for quantifying the strength of edge effects. - J. Appl. Ecol. 43: 527-536.

FABRICIUSOVÁ V., KaňUCH P. \& KRIŠTín A. 2011: Response of Orthoptera assemblages to management of montane grasslands in the Western Carpathians. — Biologia 66: 1127-1133.

Freude H., Harde K.W. \& Lohse G.A. 1966: Die Käfer Mitteleuropas, Vol. 9 Phytophaga (Cerambycidae, Chrysomelidae). Goecke \& Evers, Krefeld, 299 pp.

Freude H., Harde K.W. \& Lohse G.A. 1981: Die Käfer Mitteleuropas 10 Rhynchophora I (Curculionidae, Bruchidae). Goecke \& Evers, Krefeld, 310 pp.

Gibson D.J. 2009: Grasses and Grassland Ecology. Oxford University Press, Oxford, 305 pp.

Goulson D. 2010: Bumblebees. Behaviour, Ecology and Conservation. Oxford University Press, New York, $317 \mathrm{pp}$.

HANSEN A.J. \& DI CASTRI F. (eds) 1992: Landscape Boundaries: Consequences for Biotic Diversity and Ecological Flows. Springer, New York, 452 pp.

Hanski I. 1987: Nutritional Ecology of Dung- and Carrion-feeding Insects. In Slansky F. Jr. \& Rodrigues J.G. (eds): Nutritional Ecology of Insects, Mites and Spiders. John Wiley and Sons, New York, pp. 837-884.

HaYsom K.A. \& Coulson J.C. 1998: The Lepidoptera fauna associated with Calluna vulgaris: effects of plant architecture on abundance and diversity. - Ecol. Entomol. 23: 377-385.

Hoebeke E.R., Byers R.A., Alonso-Zarazaga M.A. \& Stimmel J.F. 2000: Ischnopterapion (Chlorapion) virens (Herbst) (Coleoptera: Curclionoidea: Brentidae: Apioninae), a Palearctic clover pest new to North America: Recognition features, distribution and bionomics. - Proc. Entomol. Soc. Wash. 102: $151-161$
HoluŠA J. 2012: Grasshoppers and bushcrickets regionally extinct in the Czech Republic: consequence of the disappearance of habitats scattered on the edge of their ranges. - J. Insect Conserv. 16: 949-960.

Hossain Z., Gurr G.M., Wratten S.D. \& Raman A. 2002: Habitat manipulation in lucerne Medicago sativa: arthropod population dynamics in harvested and 'refuge' crop strips. - J. Appl. Ecol. 39: 445-454.

Humbert J.-Y., Ghazoul J. \& Walter T. 2009: Meadow harvesting techniques and their impacts on field fauna. - Agr. Ecosyst. Environ. 130: 1-8.

Humbert J.Y., Ghazoul J., Richner N. \& Walter T. 2010: Hay harvesting causes high orthopteran mortality. - Agr. Ecosyst. Environ. 139: 522-527.

Humbert J.-Y., Ghazoul J., Richner N. \& Walter T. 2012: Uncut grass refuges mitigate the impact of mechanical meadow harvesting on orthopterans. - Biol. Conserv. 152: 96-101.

HŮRKA K. 2005: Beetles of the Czech and Slovak Republics. Kabourek, Zlín, 390 pp. [bilingual Czech/English].

Hutchinson G. 1959: Homage to Santa Rosalia, or why are there so many kinds of animals? - Am. Nat. 93: 145-159.

Isbell F., Calcagno V., Hector A., Connolly J., Harpole W.S., Reich P.B., Scherer-Lorenzen M., Schmid B., Tilman D., van Ruijven J., Weigelt A., Wilsey B.J., Zavaleta E.S. \& Loreau M. 2011: High plant diversity is needed to maintain ecosystem services. - Nature 477: 199-202.

Konvicka M., Benes J., Cizek O., Kopecek F., Konvicka O. \& VITAZ L. 2008: How too much care kills species: Grassland reserves, agri-environmental schemes and extinction of Colias myrmidone (Lepidoptera: Pieridae) from its former stronghold. - J. Insect Conserv. 12: 519-525.

Kruess A. \& TscharntKe T. 2002: Grazing intensity and the diversity of grasshoppers, butterflies and trap-nesting bees and vasps. - Conserv. Biol. 16: 1570-1580.

Kubisz D. \& Švihla V. 2013: Coleoptera: Oedemeridae. — Folia Heyrovsk. (B) 17: 1-12.

Kulfan J., ŠtrbovÁ E. \& ZaCh P. 2012: Effect of vegetation and management on occurrence of larvae and adults of generalist Maniola jurtina L. (Lepidoptera) in meadow habitats. - Pol. J. Ecol. 60: 601-609.

KuRAs T., Beneš J. \& KonviČKa M. 2000: Differing habitat affinities of four Erebia species (Lepidoptera: Nymphalidae, Satyrinae) in the Hruby Jesenik Mts, Czech Republic. — Biológia 55: 169-175.

LAIBNER S. 2000: Elateridae of the Czech and Slovak Republics. Kabourek, Zlín, 292 pp. [bilingual Czech/English].

Leksono A.S., Takada K., KoJI S., NaKagoshi N., Anggraeni T. \& NAKAMURA K. 2005: Vertical and seasonal distribution of flying beetles in a suburban temperate deciduous forest collected by water pan trap. - Insect Sci. 12: 199-206.

Lindroth C.H. 1992: Ground Beetles (Carabidae) of Fennoscandia. A Zoogeographical Study: Part 3. Part I. Specific Knowledge Regarding the Species. Smithsonian Institute Libraries and the National Science Foundation, Washington, $630 \mathrm{pp}$.

Mason N.W.H., Mouillot D., Lee W.G. \& Wilson J.B. 2005: Functional richness, functional evennes and functional divergence: the primary components of functional diversity. Oikos 111: 112-118.

MatěJková I., van Diggelen R. \& Prach K. 2003: An attempt to restore a central European species-rich mountain grassland through grazing. - Appl. Veg. Sci. 6: 161-168.

MaUdSLEY M.J. 2000: A review of the ecology and conservation of hedgerow invertebrates in Britain. - J. Environ. Manag. 60: $65-76$. 
Merckx T., Feber R.E., Riordan P., Townsend M.C., Bourn N.A.D., Parsons M.S. \& Macdonald D.W. 2009: Optimizing the biodiversity gain from agri-environment schemes. - Agr. Ecosyst. Environ. 130: 177-182.

Merckx T., Feber R.E., Mclaughlan C., Bourn N.A.D., Parsons M.S., Townsend M.C., Riordan P. \& Macdonald D.W. 2010: Shelter benefits less mobile moth species: The field-scale effect of hedgerow trees. - Agr. Ecosyst. Environ. 138: 147-151.

Miquel M.A. \& VAsKo B.N. 2014: A study of the association of Odonteus armiger (Scopoli, 1772) (Coleoptera: Geotrupidae) with the European rabbit. - J. Entomol. Zool. Stud. 1: 157-167.

Mochida O. \& Suryana T. 1976: Occurrence of the brown planthopper, Nilaparvata lugens (Homoptera: Delphacidae), on rice in Indonesia. - Rice Entomol. Newsl. 4: 39.

Moericke V. 1951: Eine Farbfalle zur Kontrolle des Fluges von Blattlausen, insbesondere der Pfisichblattlaus M. ersicae (Sulz). - Nachrbl. Dt. Pflzschutzd. 3: 23-24.

Monsevičıus V. 2004: Comparison of three methods of sampling wild bees (Hymenoptera, Apoidea) in Čepkeliai Nature Reserve (South Lithuania). - Ekologija 4: 32-39.

Mouchet M.A., Villéger S., Mason N.W.H. \& Mouillot D. 2010: Functional diversity measures: an overview of their redundancy and their ability to discriminate community assembly rules. - Funct. Ecol. 24: 867-876.

Plesník J. \& StaŇKová J. (eds) 2001: Status of Biological Resources and Implementation of the Convention on Biological Diversity in the Czech Republic. First Report. Ministry of the Environment of the Czech Republic, Prague, $72 \mathrm{pp}$.

Poschlod P. \& WallisDeVries M.F. 2002: The historical and socioeconomic perspective of calcareous grasslands - lessons from the distant and recent past. - Biol. Conserv. 104: 361-376.

READ R.W.J 1977: Notes on the Biology of Cionus scrophularia, together with preliminary observations on $\mathrm{C}$. tuberculosus and C. alauda. - Entomol. Gaz. 28: 183-202.

Robinson R.A. \& Sutherland W.J. 2002: Post-war changes in arable farming and biodiversity in Great Britain. - J. Appl. Ecol. 39: 157-176.

Rundlof M., Bengtsson J. \& Smith H.G. 2008: Local and landscape effects of organic farming on butterfly species richness and abundance. - J. Appl. Ecol. 45: 813-820.

Schmidt M.H., Roschewitz I., Thies C. \& Tscharntke T. 2005: Differential effects of landscape and management on diversity and density of ground-dwelling farmland spiders. - J. Appl. Ecol. 42: 281-287.

Shields E.J., Testa A., Neumann G., Flanders K.L. \& SchroeDER P.C. 2009: Biological control of alfalfa snout beetle with a multi-species application of locally-adapted persistent entomopathogenic nematodes: the first success. - Am. Entomol. 55: 250-257.

SJöDin N.E., Bengtsson J. \& Еквом B. 2008: The influence of grazing intensity and landscape composition on the diversity and abundance of flower-visiting insects. - J. Appl. Ecol. 45: 763-772.

SKALOŠ J. 2006: Patterns and changes of intensively utilised agricultural landscape in the Czech Republic between 1937 and 2002, aerial photography analysis. - Ekologia 21: 232-248.

Skaloš J., Weber M., LipsKÝ Z., Trpáková I., ŠAntrưČKovÁ M. UhlířovÁ L. \& KuKLA P. 2011: Using old military survey maps and orthophotograph maps to analyse long-term land cover changes - Case study (Czech Republic). - Appl. Geogr. 31: 426-438.

SLÁma M.E.F. 1998: [Longhorn Beetles (Cerambycidae) of Czech Republic and Slovakia (Beetles - Coleoptera).] By the author,
Krhanice, 383 pp. [in Czech, general parts bilingual Czech/ German].

SMReCZyŃSKi S. 1965: Coleoptera: Curculionidae: Apioninae. Identification Keys to Insects of Poland, Part 19, Vol 98 . Polish Entomological Society, Warszawa, 80 pp. [in Polish].

SMRECZYŃSKI S. 1966: Coleoptera: Curculionidae: Otiorrhynchinae, Brachyderinae. Identification Keys to Insects of Poland, Part 19, Vol 98b. Polish Entomological Society, Warszawa, $130 \mathrm{pp}$.

SMreCZYŃSKi S. 1968: Coleoptera: Curculionidae: Tanymecinae, Cleoninae, Tanyrhynchinae, Hylobiinae. Identification Keys to Insects of Poland, Part 19, Vol 98c. Polish Entomological Society, Warszawa, $106 \mathrm{pp}$.

SMRECZYŃSKI S. 1972: Coleoptera: Curculionidae: Curculioninae: Dryopthorini, Cossonini, Bagoini, Tanysphyrini, Notarini, Smicronychini, Ellescini, Acalyptini, Tychiini, Anthonomini, Curculionini, Pissodini, Magdalini, Trachodini, Rhynchophorini, Cryptorhynchini. Identification Keys to Insects of Poland, Part 19, Vol 98d. Polish Entomological Society, Warszawa, 195 pp.

Stanovský J. \& Pulpán J. 2006: Carabid beetles of Silesia (northeastern Moravia). Muzeum Beskyd, Frýdek-Místek, 159 pp. [in Czech, general parts bilingual Czech/German, English abstract].

Stoate C., Boatman N.D., Borralho R., Rio Carvalho C., De SNOo G. \& EdEn P. 2001: Ecological impacts of arable intensification in Europe. - J. Environ. Manag. 63: 337-365.

Stoate C., Báldi A., Beja P., Boatman N.D., Herzon I., van Doorn A., DE SNOO G.R., Rakosy L. \& Ramwell C. 2009: Ecological impacts of early 21 st century agricultural change in Europe - a review. - J. Environ. Manag. 91: 22-46.

Strong D.R., Lawton J.H. \& Southwood T.R.E. 1984: Insects on Plants: Community Patterns and Mechanisms. Blackwell, Oxford, $313 \mathrm{pp}$.

ŠUSTEK Z. 1981: [Carrion beetles of Czechoslovakia (Coleoptera, Silphidae).] - Zprávy Čs. Společ. Entomol. ČSAV. Klíče k určováni hmyzu 2: 46 pp. [in Czech].

Tanabe S.-I., Kholin S.K., Cho Y.-B., Hiramatsu S.-I., Ohwakı A., Kojt S., Higuchi A., Storozhenko S.Y., Nishimara S., EsaKi K., Kimura K. \& NaKamura K. 2008: A higher-taxon approach with soil invertebrates to assessing habitat diversity in East Asian rural landscapes. In Hong S.-K., Nakagoshi N., Fu B.J. \& Morimoto Y. (eds): Landscape Ecological Applications in Man-Influenced Areas: Linking Man and Nature Systems. Springer, Dordrecht, pp. 163-177.

Ter BraAk C.J.F. \& Šmilauer P. 2002: CANOCO Reference Manual and CanoDraw for Windows User's Guide: Software for Canonical Community Ordination (Version 4.5.). Microcomputer Power, Ithaca, NY.

TESAR̆ Z. 1957: Lamellicornia, Vol. 2: Scarabeidae, Laparosticti. Fauna of Czechoslovakia 11. Czechoslovak Academy of Sciences, Praha, 343 pp. [in Czech, German and Russian abstr.].

Thiele H.U. 1977: Carabid Beetles in their Environments. A Study on Habitat Selection by Adaptation in Physiology and Behaviour. Springer, Berlin, Heidelberg, New York, 369 pp.

TISCHLER W. 1949: Grundzüge der terrestrischen Tierökologie. Friedrich Vieweg, Braunschweig, 219 pp.

Vu L.V. 2009: Diversity and similarity of butterfly communities in five different habitat types at Tam Dao National Park, Vietnam. - J. Zool. 277: 15-22.

Warchalowski A. 1971: Coleoptera: Chrysomelidae: Donacinae, Orsodacninae, Criocerinae, Clytrinae, Cryptocephalinae, Lamprosomatinae, Eumolpinae. Identification Keys to Insects of Poland, Part 19, Vol 94a. Polish Entomological Society, Warszawa, $114 \mathrm{pp}$. 
Warchalowski A. 1973: Coleoptera: Chrysomelidae: Chrysomelinae, Galerucinae. Identification Keys to Insects of Poland, Part 19, Vol 94b. Polish Entomological Society, Warszawa, 97 pp.

Wilson J.S., Griswold T. \& Messinger O.J. 2008: Sampling bee communities (Hymenoptera: Apiformes) in a desert landscape: Are pan traps sufficient? - J. Kans. Entomol. Soc. 81: 288300

Woodcock B.A., Pywell R.F., Roy D.B., Rose R.J. \& Bell D. 2005: Grazing management of calcareous grasslands and its implications for the conservation of beetle communities. Biol. Conserv. 125: 193-202.

Received April 22, 2014; revised and accepted May 12, 2015 Prepublished online June 10, 2015

APPENDIX 1. Functional characteristics of beetle species and their abundances in samples collected from patches subjected to different levels of mowing.

\begin{tabular}{|c|c|c|c|c|c|c|c|c|}
\hline \multirow[t]{2}{*}{ Taxon } & \multirow{2}{*}{$\begin{array}{c}\text { Habi- } \\
\text { tat }^{\mathrm{a}}\end{array}$} & \multirow{2}{*}{$\begin{array}{l}\text { Trophic } \\
\text { group }^{\mathrm{b}}\end{array}$} & \multirow{2}{*}{$\begin{array}{l}\text { Mobi- } \\
\text { lity }^{\mathrm{c}}\end{array}$} & \multicolumn{4}{|c|}{$\begin{array}{c}\text { Level } \\
\text { of mowing }^{\mathrm{d}} \\
\end{array}$} & \multirow{2}{*}{$\begin{array}{c}\text { Total } \\
\text { abundance }\end{array}$} \\
\hline & & & & 1 & & 0.25 & 0 & \\
\hline Anthicidae & & & & & & & & \\
\hline $\begin{array}{l}\text { Notoxus monoceros } \\
\text { Brentidae }\end{array}$ & $\mathrm{O}$ & $\mathrm{C}$ & 2 & 0 & 0 & 0 & 1 & 1 \\
\hline Apion frumentarium & $\mathrm{O}$ & $\mathrm{H}$ & 2 & 0 & 0 & 0 & 3 & 3 \\
\hline $\begin{array}{l}\text { Ischnopterapion virens } \\
\text { Buprestidae }\end{array}$ & $\mathrm{O}$ & $\mathrm{H}$ & 2 & 0 & 1 & 0 & 0 & 1 \\
\hline Anthaxia helvetica & $\mathrm{M}$ & $\mathrm{N}$ & 2 & 0 & 3 & 0 & 3 & 6 \\
\hline $\begin{array}{l}\text { Anthaxia quadripunctata } \\
\text { Cantharidae }\end{array}$ & M & $\mathrm{N}$ & 2 & 28 & 19 & 2 & 26 & 75 \\
\hline Cantharis fusca & G & $\mathrm{C}$ & 2 & 2 & 0 & 0 & 17 & 19 \\
\hline Cantharis nigricans & G & $\mathrm{C}$ & 2 & 0 & 0 & 0 & 6 & 6 \\
\hline Rhagonycha fulva & G & $\mathrm{C}$ & 2 & 1 & 1 & 40 & 42 & 84 \\
\hline Rhagonycha gallica & $\mathrm{F}$ & $\mathrm{C}$ & 2 & 0 & 0 & 0 & 1 & 1 \\
\hline $\begin{array}{l}\text { Rhagonycha lignosa } \\
\text { Carabidae }\end{array}$ & $\mathrm{F}$ & $\mathrm{C}$ & 2 & 0 & 0 & 0 & 2 & 2 \\
\hline Amara aenea & $\mathrm{O}$ & $\mathrm{H}$ & 2 & 0 & 0 & 0 & 1 & 1 \\
\hline Amara aulica & $\mathrm{O}$ & $\mathrm{H}$ & 2 & 0 & 0 & 0 & 1 & 1 \\
\hline Amara nitida & G & $\mathrm{H}$ & 2 & 0 & 0 & 0 & 1 & 1 \\
\hline Carabus granulatus & $\mathrm{F}$ & $\mathrm{C}$ & 1 & 1 & 0 & 0 & 3 & 4 \\
\hline Carabus scheidleri & G & $\mathrm{C}$ & 1 & 1 & 0 & 0 & 0 & 1 \\
\hline Carabus violaceus & G & $\mathrm{C}$ & 1 & 0 & 0 & 0 & 1 & 1 \\
\hline Dromius agilis & $\mathrm{F}$ & $\mathrm{C}$ & 2 & 1 & 0 & 0 & 0 & 1 \\
\hline Harpalus affinis & $\mathrm{O}$ & $\mathrm{H}$ & 2 & 0 & 0 & 0 & 7 & 7 \\
\hline Ophonus rufibarbis & $\mathrm{O}$ & $\mathrm{H}$ & 2 & 0 & 0 & 0 & 1 & 1 \\
\hline Poecillus cupreus & $\mathrm{O}$ & $\mathrm{O}$ & 2 & 0 & 1 & 1 & 36 & 38 \\
\hline Pseudoofonus rufipes & $\mathrm{O}$ & $\mathrm{H}$ & 2 & 0 & 0 & 1 & 0 & 1 \\
\hline Pterostichus melanarius & G & $\mathrm{C}$ & 1 & 0 & 0 & 0 & 1 & 1 \\
\hline Pterostichus niger & $\mathrm{F}$ & $\mathrm{C}$ & 1 & 0 & 0 & 0 & 1 & 1 \\
\hline $\begin{array}{l}\text { Pterostichus oblongopunctatus } \\
\text { Cerambycidae }\end{array}$ & $\mathrm{F}$ & $\mathrm{C}$ & 1 & 0 & 0 & 0 & 1 & 1 \\
\hline Agapanthia intermedia & $\mathrm{O}$ & $\mathrm{H}$ & 2 & 0 & 0 & 0 & 1 & 1 \\
\hline Alosterna tabacicolor & M & $\mathrm{N}$ & 2 & 0 & 0 & 0 & 2 & 2 \\
\hline Aromia moschata & M & $\mathrm{N}$ & 2 & 0 & 0 & 0 & 1 & 1 \\
\hline Evodinus clathratus & M & $\mathrm{N}$ & 2 & 0 & 0 & 0 & 1 & 1 \\
\hline Leptura maculicornis & M & $\mathrm{N}$ & 2 & 0 & 0 & 0 & 1 & 1 \\
\hline Pseudovadonia livida & M & $\mathrm{N}$ & 2 & 0 & 0 & 0 & 2 & 2 \\
\hline $\begin{array}{l}\text { Stictoleptura rubra } \\
\text { Chrysomelidae }\end{array}$ & M & $\mathrm{N}$ & 2 & 0 & 0 & 1 & 1 & 2 \\
\hline Chrysolina fastuosa & G & $\mathrm{H}$ & 2 & 0 & 0 & 0 & 2 & 2 \\
\hline Chrysolina oricalcia & G & $\mathrm{H}$ & 2 & 0 & 0 & 0 & 1 & 1 \\
\hline Chrysolina staphylea & $\mathrm{O}$ & $\mathrm{H}$ & 2 & 0 & 0 & 0 & 1 & 1 \\
\hline Cryptocephalus moraei & M & $\mathrm{H}$ & 2 & 12 & 17 & 2 & 112 & 143 \\
\hline Cryptocephalus sericeus & $\mathrm{O}$ & $\mathrm{H}$ & 2 & 18 & 17 & 57 & 206 & 298 \\
\hline Galeruca tanaceti & $\mathrm{O}$ & $\mathrm{H}$ & 1 & 0 & 0 & 2 & 6 & 8 \\
\hline Galerucella tenella & $\mathrm{O}$ & $\mathrm{H}$ & 2 & 0 & 1 & 0 & 1 & 2 \\
\hline $\begin{array}{l}\text { Plateumaris consimilis } \\
\text { Coccinellidae }\end{array}$ & $\mathrm{O}$ & $\mathrm{H}$ & 2 & 0 & 0 & 0 & 3 & 3 \\
\hline Adalia bipunctata & M & $\mathrm{C}$ & 2 & 1 & 0 & 0 & 0 & 1 \\
\hline Anatis ocellata & $\mathrm{F}$ & $\mathrm{C}$ & 2 & 1 & 0 & 0 & 0 & 1 \\
\hline Chilocorus renipustulatus & $\mathrm{F}$ & $\mathrm{C}$ & 2 & 0 & 0 & 0 & 1 & 1 \\
\hline Coccinella septempunctata & $\mathrm{O}$ & $\mathrm{C}$ & 2 & 3 & 9 & 6 & 46 & 64 \\
\hline Harmonia axyridis & G & $\mathrm{C}$ & 2 & 0 & 4 & 0 & 1 & 5 \\
\hline Hippodamia variegata & $\mathrm{O}$ & $\mathrm{C}$ & 2 & 0 & 0 & 0 & 1 & 1 \\
\hline Propylea quatuordecimpunctata & G & $\mathrm{C}$ & 2 & 2 & 1 & 1 & 2 & 6 \\
\hline Psyllobora vigintiduopunctata & G & $\mathrm{J}$ & 2 & 0 & 0 & 0 & 1 & 1 \\
\hline
\end{tabular}

\begin{tabular}{|c|c|c|c|c|c|c|c|c|}
\hline \multirow[t]{2}{*}{ Taxon } & \multirow{2}{*}{$\begin{array}{c}\text { Habi- } \\
\text { tat }^{\mathrm{a}}\end{array}$} & \multirow{2}{*}{$\begin{array}{l}\text { Trophic } \\
\text { group }^{\mathrm{b}}\end{array}$} & \multirow{2}{*}{$\begin{array}{l}\text { Mobi- } \\
\text { lity }^{\mathrm{c}}\end{array}$} & \multicolumn{4}{|c|}{$\begin{array}{c}\text { Level } \\
\text { of mowing }\end{array}$} & \multirow{2}{*}{$\begin{array}{c}\text { Total } \\
\text { bundance }\end{array}$} \\
\hline & & & & 1 & 0.5 & 0.25 & 0 & \\
\hline Cryptophagidae & & & & & & & & \\
\hline $\begin{array}{l}\text { Antherophagus nigricornis } \\
\quad \text { Curculionidae }\end{array}$ & M & $\mathrm{O}$ & 2 & 1 & 0 & 2 & 2 & 5 \\
\hline Anthonomus rubi & G & $\mathrm{H}$ & 2 & 0 & 0 & 0 & 1 & 1 \\
\hline Cionus tuberculosus & G & $\mathrm{H}$ & 2 & 0 & 0 & 0 & 1 & 1 \\
\hline Hypera plantaginis & $\mathrm{O}$ & $\mathrm{H}$ & 2 & 0 & 0 & 0 & 1 & 1 \\
\hline Otiorhynchus ligustici & $\mathrm{O}$ & $\mathrm{H}$ & 1 & 0 & 1 & 0 & 1 & 2 \\
\hline Sitona lineatus & G & $\mathrm{H}$ & 1 & 0 & 0 & 0 & 1 & 1 \\
\hline Sitona sulcifrons & G & $\mathrm{H}$ & 1 & 0 & 0 & 0 & 1 & 1 \\
\hline $\begin{array}{l}\text { Trachyphloeus bifoveolatus } \\
\text { Elateridae }\end{array}$ & G & $\mathrm{H}$ & 1 & 0 & 0 & 0 & 1 & 1 \\
\hline Agriotes obscurus & $\mathrm{O}$ & $\mathrm{H}$ & 2 & 0 & 0 & 0 & 10 & 10 \\
\hline Agriotes ustulatus & $\mathrm{O}$ & $\mathrm{H}$ & 2 & 0 & 0 & 0 & 2 & 2 \\
\hline Agrypnus murinus & $\mathrm{O}$ & $\mathrm{H}$ & 2 & 0 & 1 & 1 & 9 & 11 \\
\hline Athous haemorrhoidalis & G & $\mathrm{H}$ & 2 & 0 & 0 & 0 & 3 & 3 \\
\hline Ctenicera pectinicornis & $\mathrm{O}$ & $\mathrm{H}$ & 2 & 0 & 0 & 0 & 2 & 2 \\
\hline $\begin{array}{l}\text { Selatosomus aeneus } \\
\text { Geotrupidae }\end{array}$ & $\mathrm{F}$ & $\mathrm{H}$ & 2 & 0 & 0 & 0 & 3 & 3 \\
\hline Anoplotrupes stercorosus & $\mathrm{F}$ & $\mathrm{S}$ & 2 & 0 & 0 & 1 & 27 & 28 \\
\hline Odonteus armiger & $\mathrm{O}$ & $\mathrm{J}$ & 1 & 0 & 0 & 0 & 1 & 1 \\
\hline $\begin{array}{l}\text { Trypocopris vernalis } \\
\text { Histeridae }\end{array}$ & G & $\mathrm{S}$ & 2 & 1 & 0 & 1 & 2 & 4 \\
\hline $\begin{array}{l}\text { Margarinotus striola } \\
\text { Hydrophilidae }\end{array}$ & G & $\mathrm{D}$ & 2 & 0 & 0 & 0 & 1 & 1 \\
\hline $\begin{array}{l}\text { Anacaena globulus } \\
\text { Kateretidae }\end{array}$ & G & $\mathrm{C}$ & 2 & 0 & 0 & 0 & 1 & 1 \\
\hline $\begin{array}{l}\text { Brachypterus glaber } \\
\text { Lampyridae }\end{array}$ & G & $\mathrm{N}$ & 2 & 0 & 2 & 0 & 0 & 2 \\
\hline Lamprohiza splendidula & G & - & 1 & 0 & 4 & 0 & 5 & 9 \\
\hline $\begin{array}{l}\text { Leiodidae } \\
\text { Anisotoma humeralis } \\
\text { Melyridae }\end{array}$ & $\mathrm{F}$ & $\mathrm{J}$ & 2 & 0 & 0 & 0 & 1 & 1 \\
\hline $\begin{array}{l}\text { Dasytes obscurus } \\
\text { Oedemeridae }\end{array}$ & G & $\mathrm{N}$ & 2 & 0 & 0 & 1 & 3 & 4 \\
\hline Chrysanthia viridissima & M & $\mathrm{N}$ & 2 & 0 & 0 & 0 & 2 & 2 \\
\hline $\begin{array}{l}\text { Oedemera virescens } \\
\text { Scarabaeidae }\end{array}$ & $\mathrm{O}$ & $\mathrm{N}$ & 2 & 1 & 1 & 0 & 12 & 14 \\
\hline Aphodius rufipes & $\mathrm{O}$ & $\mathrm{S}$ & 2 & 0 & 0 & 0 & 2 & 2 \\
\hline Oxythyrea funesta & $\mathrm{O}$ & $\mathrm{N}$ & 2 & 2 & 10 & 17 & 56 & 85 \\
\hline Phyllopertha horticola & G & $\mathrm{H}$ & 2 & 2 & 0 & 0 & 139 & 141 \\
\hline Serica brunnea & $\mathrm{O}$ & $\mathrm{H}$ & 2 & 0 & 2 & 0 & 8 & 10 \\
\hline $\begin{array}{l}\text { Trichius fasciatus } \\
\text { Silphidae }\end{array}$ & M & $\mathrm{N}$ & 2 & 0 & 0 & 0 & 1 & 1 \\
\hline Nicrophorus humator & $\mathrm{F}$ & $\mathrm{D}$ & 2 & 0 & 0 & 0 & 2 & 2 \\
\hline Nicrophorus interruptus & $\mathrm{O}$ & $\mathrm{D}$ & 2 & 0 & 0 & 1 & 5 & 6 \\
\hline Nicrophorus investigator & G & $\mathrm{D}$ & 2 & 0 & 0 & 0 & 3 & 3 \\
\hline Nicrophorus vespillo & $\mathrm{O}$ & $\mathrm{D}$ & 2 & 12 & 2 & 11 & 130 & 155 \\
\hline Nicrophorus vespilloides & $\mathrm{F}$ & $\mathrm{D}$ & 2 & 0 & 3 & 5 & 54 & 62 \\
\hline Oiceptoma thoracicum & $\mathrm{F}$ & $\mathrm{D}$ & 2 & 1 & 0 & 1 & 5 & 7 \\
\hline Phosphuga atrata & G & $\mathrm{C}$ & 1 & 3 & 0 & 0 & 17 & 20 \\
\hline Silpha carinata & $\mathrm{F}$ & $\mathrm{C}$ & 1 & 1 & 5 & 3 & 105 & 114 \\
\hline Silpha obscura & G & $\mathrm{C}$ & 1 & 0 & 10 & 1 & 40 & 51 \\
\hline Silpha tristis & G & $\mathrm{C}$ & 1 & 0 & 6 & 29 & 10 & 45 \\
\hline Thanatophilus sinuatus & $\mathrm{O}$ & $\mathrm{D}$ & 2 & 4 & 3 & 3 & 44 & 54 \\
\hline $\begin{array}{l}\text { Thanatophilus rugosus } \\
\text { Staphylinidae }\end{array}$ & $\mathrm{O}$ & $\mathrm{D}$ & 2 & 0 & 2 & 0 & 1 & 3 \\
\hline Ontholestes murinus & $\mathrm{O}$ & $\mathrm{C}$ & 2 & 0 & 2 & 0 & 1 & 3 \\
\hline Ontholestes tesselatus & G & $\mathrm{C}$ & 2 & 0 & 0 & 0 & 1 & 1 \\
\hline Oxyporus rufus & G & $\mathrm{C}$ & 2 & 0 & 0 & 0 & 1 & 1 \\
\hline Philonthus marginatus & $\mathrm{O}$ & $\mathrm{C}$ & 2 & 0 & 0 & 0 & 1 & 1 \\
\hline
\end{tabular}

${ }^{a}$ Forest species are abbreviated as $(\mathrm{F})$, open habitat species as $(\mathrm{O})$, species with preference for transitional stages, mosaics of open habitats, shrubs and trees as (M), habitat generalists as (G). ${ }^{b}$ Herbivorous species are abbreviated as $(\mathrm{H})$, pollen and nectar feeders as $(\mathrm{N})$, carnivores as $(\mathrm{C})$, saprophagous species as (S), necrophagous as (D), fungivorous as (J) and omnivorous as $(\mathrm{O}) .{ }^{\mathrm{c}}$ Local, sedentary species including weakly mobile brachypterous beetles were categorized as (1), vagile species with high mobility as (2). ${ }^{\mathrm{d}}$ The intensity of mowing is coded as: 1, 0.5, 0.25, 0 (for more details see Data arrangement in $\mathrm{M} \& \mathrm{M}$ ). 